\title{
Denitrification rates as measured by the isotope pairing method and by the acetylene inhibition technique in continental shelf sediments of the North Sea
}

\author{
Lutz Lohse*, Henderikus T. Kloosterhuis, Wim van Raaphorst, Willem Helder
}

Netherlands Institute for Sea Research (NIOZ), PO Box 59, 1790 AB Den Burg, Texel, The Netherlands

\begin{abstract}
Denitrification rates in continental shelf sediments of the North Sea were measured by the simultaneous application of the acetylene inhibition technique (AIT) and the isotope pairing method (IPM). Nitrification was the predominant source of nitrate in these sediments. Both techniques were able to detect coupled nitrification-denitrification activity. Denitrification rates measured by the AIT were only measurable during the first $60 \mathrm{~min}$ of the incubation. Rates obtained by the AIT in this period ranged between 5.4 and $7.3 \mu \mathrm{mol} \mathrm{N} \mathrm{m} \mathrm{N}^{-2} \mathrm{~h}^{-1}$ Continued incubation of acetylene amended sediment cores resulted in decreasing denitrification rates, suggesting that accumulated nitrous oxide was consumed despite the presence of acetylene. Denitrification rates obtained by the application of the IPM ranged between 9.8 and $13.2 \mu \mathrm{mol} \mathrm{N} \mathrm{m} \mathrm{N}^{-2} \mathrm{~h}^{-1}$ Constant production of single-labelled $\left({ }^{14} \mathrm{~N}^{15} \mathrm{~N}\right)$ relative to double-labelled $\left({ }^{15} \mathrm{~N}^{15} \mathrm{~N}\right)$ dinitrogen indicated a homogeneous mixing of both isotopic nitrate species through the denitrification zone. The present results suggest that previously published data severely underestimated denitrification rates in North Sea continental shelf sediments. Concomitant measured fluxes of nitrate and ammonium across the sediment-water interface reveal that in these sediments most of the deposited nitrogen is returned to the water column as ammonium and nitrate.
\end{abstract}

KEY WORDS: Denitrification N Nitrification - Isotope pairing method Acetylene inhibition technique Nitrate fluxes · Continental shelf sediments

\section{INTRODUCTION}

Denitrification is the successive reduction of fixed $\mathrm{NO}_{3}{ }^{-}$and $\mathrm{NO}_{2}{ }^{-}$to gaseous $\mathrm{N}_{2} \mathrm{O}$ and to $\mathrm{N}_{2}$ and can be considered as one of the key processes in global and marine nitrogen cycles. The bacterially mediated process occurs in the absence of oxygen, primarily close to the anoxic-oxic interface as encountered in e.g. coastal sediments. At such a site, denitrifying bacteria receive $\mathrm{NO}_{3}{ }^{-}$by diffusion either from the overlying water or from the oxic sediment surface layer, where ammonium is oxidised to nitrate. The latter process, called nitrification, is considered as the predominating nitrate source for denitrification in most coastal sediments (Seitzinger 1988).

\footnotetext{
•E-mail: lutz@nioz.nl
}

Numerous studies demonstrated the significance of benthic denitrification in the nitrogen budget of estuarine, coastal and shelf sea areas (e.g. Nishio et al. 1983, Jensen et al. 1988, Devol \& Christensen 1993). It has been estimated that up to $80 \%$ of the external nitrogen load to coastal areas can be removed by denitrification (overview in Seitzinger 1990). Therefore, this process not only plays an important role in counteracting eutrophication effects (Rönner 1985), but it may also affect pelagic production (Nixon 1981). In order to measure denitrification rates quantitatively, considerable efforts have been made to develop sophisticated methods which permit their detection in marine sediments under in situ conditions.

The most direct approach is to measure the evolution of $\mathrm{N}_{2}$ and $\mathrm{N}_{2} \mathrm{O}$ in the water or gas phase of enclosed benthic chambers (Seitzinger et al. 1980). The major 
advantage of this method is that no inhibitors or artificial substrates are required and in principle the method can be applied in situ with benthic landers (Devol \& Christensen 1993) Normally, the $\mathrm{N}_{2}$ containing overlying water has to be replaced with $\mathrm{He} / \mathrm{O}_{2}$ flushed water and the sediment cores have to be preincubated for up to $10 \mathrm{~d}$ to lower the background $\mathrm{N}_{2}$ concentrations in the porewater. During the preincubation, the heterotrophic denitrification activity may be influenced by an exhaustion of the labile organic carbon pool. A recent modification diminished the preincubation time to 3 or $4 \mathrm{~d}$, but, due to incomplete removal of $\mathrm{N}_{2}$ from the porewater, this resulted in relative high background fluxes of $\mathrm{N}_{2}$ which have to be subtracted from the true denitrification rate (Nowicki 1994). In any case, this approach is sensitive to contamination with atmospheric nitrogen gas. The present detection limit of $-25 \mu \mathrm{mol} \mathrm{N} \mathrm{m}^{-2} \mathrm{~h}^{-1}$ (Seitzinger 1987) excludes the application of this technique in aquatic sediments with low activity.

The most frequently used method up until now has been the acetylene inhibition technique (Sørensen 1978). This method is based on the accumulation of $\mathrm{N}_{2} \mathrm{O}$ due to the inhibition of the nitrous oxide reductase enzyme by acetylene (Yoshinari \& Knowles 1976). Although far more rapid and easier to apply than the $\nu_{\text {: }}$ evolution technique, several methodological constraints must be taken into account. Particularly, the co-inhibition of nitrification by acetylene may lead to an exhaustion of the porewater nitrate pool which in turn can lead to an underestimate of the true denitrification rate. Additionally, studies with combined microsensors for nitrous oxide and oxygen have shown that $\mathrm{N}_{2} \mathrm{O}$ may be partly reduced to $\mathrm{N}_{2}$ despite the presence of acetylene (Christensen et al. 1989). Nevertheless, this technique continues to be applied extensively in marine sediments (Kemp et al. 1990, Law \& Owens 1990, Blackburn et al. 1994. Thompson et al. 1995).

The applicability of stable isotopes in denitrification studies was improved by the introduction of the isotope pairing method (Nielsen 1992). This approach facilitates the determination of the reduction of both $\mathrm{NO}_{3}{ }^{-}$diffusing downwards from the overlying water and of $\mathrm{NO}_{3}$ produced through nitrification. Basically, ${ }^{15} \mathrm{NO}_{3}{ }^{-}$added to the overlying water is allowed to diffuse through the oxic sediment layer to the denitrification zone. According to the stoichiometry of denitrification, added ${ }^{15} \mathrm{NO}_{3}^{-}$pairs with indigenous ${ }^{14} \mathrm{NO}_{3}{ }^{-}$ originate either from nitrification or from the overlying water Reduction of ${ }^{14} \mathrm{NO}_{3}{ }^{-}$and ${ }^{15} \mathrm{NO}_{3}$ results in the formation of the isotopes ${ }^{14} \mathrm{~N}^{14} \mathrm{~N},{ }^{14} \mathrm{~N}^{15} \mathrm{~N}$, and ${ }^{15} \mathrm{~N}^{15} \mathrm{~N}$ Crucial assumptions in this technique are that (1) the rate of coupled nitrification-denitrification is not influenced by the addition of labelled nitrate and (2) the ${ }^{15} \mathrm{NO}_{3}{ }^{-}$added to the overlying water mixes homoge- neously with the ${ }^{14} \mathrm{NO}_{3}$ pool down to the zone where denitrification occurs. The latter prerequisite is most easily met in sediments where the oxygenated layer is restricted to a few millimetres.

Although the limitations of the methods have been addressed in several denitrification studies, systematic comparisons are rarely performed. Seitzinger et al. (1993) carried out a comparative experiment incubating lake sediments under controlled conditions, in which denitrification rates were measured with the $\mathrm{N}_{2}$ flux method, the acetylene inhibition technique, and a ${ }^{15} \mathrm{~N}$ tracer approach (Nishio et al. 1983). In that particular study, the $\mathrm{N}_{2}$ flux technique consistently gave highest rates, while rates obtained with the ${ }^{15} \mathrm{~N}$ tracer technique were low and more variable. The acetylene block technique, however, failed to detect any nitrous oxide produced by coupled nitrification-denitrification activity.

In this study, we compare results from an experiment carried out on the continental shelf of the North Sea. The acetylene inhibition technique and the isotope pairing technique were used to determine in situ denitrification rates in sediments overlain by a welloxygenated water column with low nitrate concentrations. Our main objective was to compare the outcomes of both techniques and to reexamine previous measurements in this area based on the acetylene inhibition technique only. All experiments were conducted during the STED expedition (Short Term Dynamics of benthic microbial activities and nutrient fluxes related to sedimentation and current velocities) in July 1994 aboard the RV 'Pelagia'

\section{MATERIALS AND METHODS}

Characterisation of the study site. Samples were collected at the Oysterground mooring station $\left(54^{\circ} 25.46^{\prime}\right.$ $N, 4^{\circ} 02.16^{\prime} \mathrm{E}$ ) in the central part of the southern North Sea. The water column was stratified by a thermocline with surface and bottom water temperatures of 17 and $9^{\circ} \mathrm{C}$, respectively. The salinity ranged around $34.5 \%$ throughout the water column. Bottom water oxygen concentrations $\left(-261 \mu \mathrm{mol} \mathrm{l^{-1 }}\right)$ did not differ substantially from saturation values. Nitrate and ammonium concentrations in the bottom water did not exceed concentrations of $1 \mu \mathrm{M}$.

According to the Wentworth scale, the sediments consisted of very fine sands, having an average porosity of $0.55(\mathrm{v} / \mathrm{v})$ in the upper $5 \mathrm{~mm}$. Previous investigations showed that the organic carbon and nitrogen content (averaged over the first $5 \mathrm{~mm}$ ) were 0.12 and $0.02 \%$, respectively (Lohse et al. 1993).

Sample collection. Sediment cores were obtained by gently pushing acrylic liners into the sediment re- 
trieved on deck by a cylindrical boxcorer (for details, see Lohse et al. 1993). Only boxcores without visible disturbance of the sediment water interface were used for subcoring. All processes reported in this study were measured on 3 different days, denoted here as Expts A. ( 8 July), B (14 July), C ( 7 July) and E (17 July). The distance between the sample location was $<200 \mathrm{~m}$. The experiments were carried out in a thermostated container which was adjusted to in situ temperature $\left( \pm 0.5^{\circ} \mathrm{C}\right)$.

Denitrification assays. Sediment cores were taken with acrylic liners $(23 \mathrm{~cm}$ length, $3.6 \mathrm{~cm}$ i.d.). The sediment was adjusted in height so that the cores contained approximately $5 \mathrm{~cm}$ of sediment column and $15 \mathrm{~cm}$ of overlying water. The uncapped sediment cores were carefully immersed in an aquarium containing bottom water from the sampling location. The overlying water in the cores was stirred by a small rotating magnet, located $2 \mathrm{~cm}$ above the sedimentwater interface. The momentum of these magnets was switched from clockwise to anticlockwise rotation every $5 \mathrm{~s}$ in order to minimise the effect of pressure gradients at the sediment water interface caused by one-directional flow patterns. All cores were preincubated for 2 to $3 \mathrm{~h}$ prior to further treatments.

Acetylene inhibition technique (AIT): The conventional acetylene-block technique (Sørensen 1978) was modified according to Christensen et al. (1989). Commercial grade acetylene gas (Hoekloos Ltd, Amsterdam, The Netherlands) was purified by scrubbing the gas in concentrated sulphuric acid and $5 \mathrm{M} \mathrm{NaOH}$ (Hyman \& Arp 1987). Four to 10 sediment cores were amended with water saturated with purified acetylene following the procedure previously described in Lohse et al. (1993). The final concentration of acetylene in the overlying water and in the porewater was $10 \mathrm{kPa}$. Two additional sediment cores received no acetylene and served as control. The cores were then capped and incubated for between 20 and $120 \mathrm{~min}$. Nitrous oxide in the overlying water was analysed after transferring a $10 \mathrm{ml}$ sample into a $30 \mathrm{ml}$ extraction vial. The vial was shaken vigorously for $10 \mathrm{~min}$ to achieve equilibrium between headspace and water. A $3 \mathrm{ml}$ sample of the gas phase was transferred into an evacuated vacutainer (Terumo, Belgium). After taking a second water sample $(20 \mathrm{ml})$ for dissolved nutrient analysis, the core was capped again and the remaining overlying water, along with the sediment, was shaken vigorously for 15 min. Again, a gas sample was drawn from the headspace and transferred into an evacuated vacutainer. Nitrous oxide in the vacutainers was analysed on a Packard 438a gas chromatograph equipped with an electron capture detector (for details, see Lohse et al. 1993). The concentration of $\mathrm{N}_{2} \mathrm{O}$ in water was calculated using the solubility coefficients of $\mathrm{N}_{2} \mathrm{O}$ in seawa- ter (Weiss \& Price 1980). The vacutainers contained an elevated background concentration of nitrous oxide $(430 \pm 25 \mathrm{ppb})$ which was taken into account for all calculations. The denitrification rate was calculated from the total increase of nitrous oxide in the porewater and overlying water of individual cores.

Isotope pairing method (IPM): Denitrification rates were estimated in 6 to 10 sediment cores by adding $20 \mathrm{ml}$ of a labelled $50 \mathrm{mM}{ }^{15} \mathrm{NO}_{3}{ }^{-}$solution $(98$ atom\%, Sigma Ltd, UK) to the bulk water of the aquarium $(-19$ 1). This resulted in a final nitrate concentration in the aquarium water of between 61 and $83 \mu \mathrm{M}$ ${ }^{15} \mathrm{NO}_{3}{ }^{-}$. The cores remained uncapped for another $30 \mathrm{~min}$, to facilitate a homogeneous distribution of nitrate between the overlying water of the cores and the surrounding aquarium water. Subsequently, all cores were capped with rubber stoppers and incubated for 25 to $180 \mathrm{~min}$. The formation of ${ }^{15} \mathrm{~N}$ labelled dinitrogen was analysed by terminating the incubation of single cores in 20 to $45 \mathrm{~min}$ intervals. A subsample of $40 \mathrm{ml}$ was taken from the overlying water with a plastic syringe. Part of this sample was carefully transferred into two $12.6 \mathrm{ml}$ exetainers (Labco Ltd, Bucks, UK) which were closed by a screw cap equipped with a gastight injection septum. The exetainer contained $250 \mu$ of a $50 \%(\mathrm{w} / \mathrm{w}) \mathrm{ZnCl}_{2}$ solution to prevent further microbial activity. The water left in the syringe was used for immediate analysis of nutrients. An additional amount of $3 \mathrm{ml}$ of the $\mathrm{ZnCl}_{2}$ solution was added to the remaining overlying water in the core, which was then mixed gently with the whole sediment column to produce a slurry. Similar to the analysis of the water phase, a subsample of this slurry was transferred into 2 additional exetainers which contained $250 \mu \mathrm{l}$ of $\mathrm{ZnCl}_{2}$ solution

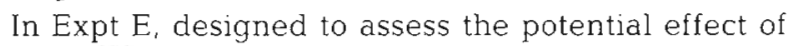
labelled ${ }^{15} \mathrm{NO}_{3}{ }^{-}$on the first-order kinetics of denitrification, 13 cores were enriched with varying concentrations of ${ }^{15} \mathrm{NO}_{3}{ }^{-}$. This was achieved by adding different aliquots of a $5 \mathrm{mM}^{15} \mathrm{NO}_{3}{ }^{-}$stock solution to the water column of single cores, resulting in concentrations between 15 and $180 \mu \mathrm{M}^{15} \mathrm{NO}_{3}{ }^{-}$The incubation was terminated after $150 \mathrm{~min}$, according to the procedure described above. All exetainers were stored at $4^{\circ} \mathrm{C}$ until analysis, which took place within 5 wk after sampling.

Dissolved labelled and unlabelled $\mathrm{N}_{2}$ was extracted from the water phase of the exetainer by replacing $4 \mathrm{ml}$ of water in the exetainer with helium gas. By vigorous shaking for 5 min more than $98 \%$ of $\mathrm{N}_{2}$ from the water phase was transferred into the headspace of the exetainer (Weiss 1970). The first set of exetainers was analysed at the National Environmental Research Centre (NERI) in Silkeborg, Denmark. Analysis was performed with a Tracermass stable isotope mass spec- 
trometer (Europa Scientific, Crewe, UK) equipped with a triple collector system. The complete sample headspace was injected by an autosampler (RoboPrebG+) equipped with a helium flushed needle system. The gas was purified in a glass column packed with Drierite and Carbosorb. Additionally, the gas flow was lead through a heated copper reduction tube $\left(600^{\circ} \mathrm{C}\right)$. The standard error of repeated single injections was less than $1.6 \%$. The denitrification rate was calculated from the increase of labelled isotopes in individual cores.

To establish an intercomparison with data obtained at NERI, we analysed a duplicate set of samples on the stable isotope mass spectrometer (VG Isotech Fisons Optima, Middlewich, UK) at the Netherlands Institute for Sea Research (NIOZ). Both mass spectrometers had essentially the same technical manifold, although at the NIOZ, smaller subsamples $(400 \mu l)$ of the headspace gas were injected manually using a gas-tight Hamilton syringe. The readings of both mass spectrometers showed excellent agreement (data not shown).

Calculation of denitrification rates. Analysis of the isotopic composition of the injected gases results in currents of ${ }^{14} \mathrm{~N}^{14} \mathrm{~N}$ (mass 28), ${ }^{14} \mathrm{~N}^{15} \mathrm{~N}$ (mass 29), and ${ }^{15} \mathrm{~N}^{15} \mathrm{~N}$ (mass 30 ). The sample ratios $\mathrm{R} 1$ and $\mathrm{R} 2$ are obtained by dividing the 29 and the 30 current by the sum of the 28,29 and 30 current. The corresponding reference ratios (obtained from exetainers containing only seawater from the sampling station) are subtracted from the sample ratios. The amount of ${ }^{14} \mathrm{~N}^{-15} \mathrm{~N}$ and ${ }^{15} N^{15} N$ isotopes (in nmol) was calculated by multiplying $\mathrm{R} 1$ and $\mathrm{R} 2$ with the total amount of $\mathrm{N}_{2}$ present in the headspace and the water of the exetainer. The amount of $\mathrm{N}_{2}$ extracted from the exetainer was determined from the distribution coefficient of $\mathrm{N}_{2}$ between water and atmosphere (Weiss 1970). Calibration for $\mathrm{N}_{2}$ took place by injecting 20,40 and $60 \mu$ l of air into the headspace of the exetainers.

Rates of denitrification were calculated from the production of single-labelled ${ }^{14} \mathrm{~N}^{15} \mathrm{~N}$ relative to doublelabelled ${ }^{15} \mathrm{~N}^{15} \mathrm{~N}$ following the calculations of Nielsen (1992). Homogenous mixing of both nitrate species results in a binomial distribution of all dinitrogen species formed, so that ${ }^{14} \mathrm{~N}^{15} \mathrm{~N}$ and ${ }^{15} \mathrm{~N}^{15} \mathrm{~N}$ are produced with the probability of $2 \mathrm{~N}^{14} \mathrm{~N}^{15}$ and $1 \mathrm{~N}^{15} \mathrm{~N}^{15}$ (Hauck et al. 1958). The denitrification rate of labelled nitrate $\left(D_{15}\right)$ is calculated as the sum of all labelled $N_{2}$ species formed:

$$
D_{15}=\left({ }^{14} N^{15} N\right)+2\left({ }^{15} N^{15} N\right) .
$$

The denitrification rate based on unlabelled nitrate $\left(D_{14}\right)$, representing in situ denitrification, relies on the assumed binomial distribution and is derived from:

$$
D_{14}=\left({ }^{14} N^{15} \mathrm{~N}\right) / 2\left({ }^{15} N^{15} N\right) \times D_{15} .
$$

The rate of $D_{14}$ is supported by nitrate diffusing into the sediment from the overlying water (Dw) and by nitrate that is produced by nitrification in the oxic layer of the sediment (Dn). The former is calculated as:

$$
\mathrm{Dw}=(100-\mathrm{e} 15) / \mathrm{e} 15 \times \mathrm{D}_{15}
$$

where e15 is the percentage of ${ }^{15} \mathrm{NO}_{3}{ }^{-}$enrichment of the total nitrate pool in the overlying water. Denitrification coupled to nitrification (Dn) is then simply calculated from the difference:

$$
\mathrm{Dn}=\mathrm{D}_{14}-\mathrm{Dw}
$$

Oxygen microprofiles and nutrient fluxes. Three sediment cores $(25 \mathrm{~cm}$ length, $10 \mathrm{~cm}$ i.d.) were taken for the determination of oxygen porewater profiles and nutrient fluxes at each denitrification experiment. The cores were preincubated for $2 \mathrm{~h}$ prior to measurements. The water column was continuously stirred by a small Teflon coated magnet, switching rotation direction from clockwise to anticlockwise every $5 \mathrm{~s}$. Three to 6 oxygen profiles were made with Clarktype microelectrodes (Diamond Corp., Ann Arbor, USA; type 737) at different horizontal positions at the sediment surface. The average tip diameter of the electrodes was $85 \mu \mathrm{m}$. Typical output at $100 \% \mathrm{O}_{2}$ saturation at ambient conditions $\left(9^{\circ} \mathrm{C}, 34.5 \%\right.$ S $)$ was 250 to $300 \mathrm{pA}$, while the zero signal in anoxic sediments ranged between 10 and $20 \mathrm{pA}$. Ninety percent of the output signal was obtained in $<3 \mathrm{~s}$. The oxygen concentration in the bottom water was determined by an automated Winkler titration in triplicate. The electrodes were calibrated by assuming a linear relationship between the oxygen concentration and the output signal (Revsbech \& Jørgensen 1986). The electrodes were inserted in steps of $100 \mu \mathrm{m}$ using a motor-driven micromanipulator with computerised depth control. The oxygen uptake of the sediment was calculated by applying a zero-order consumption model according to Bouldin (1968).

Nutrient fluxes were determined simultaneously in these cores by taking $10 \mathrm{ml}$ samples from the overlying water at intervals of $20 \mathrm{~min}$. Ammonium, nitrate and nitrite were determined using standard methods for nitrate (Strickland \& Parsons 1972) and ammonium (Helder \& de Vries 1979) using a TRAACS-800 autoanalyser. The analytical precision of these measurements was $1 \%$ for nitrate and $2 \%$ for ammonium.

Porewater profiles. Porewater profiles of dissolved ammonium and nitrate were made by pushing the sediment out of acrylic liners $(30 \mathrm{~cm}$ length, $3.6 \mathrm{~cm}$ i.d.) and sectioning it into intervals of $0-2.5,2.5-5,5-7.5$, $7.5-10,10-15,15-20,20-25,25-30,30-40,40-50$, $50-60$ and $60-70 \mathrm{~mm}$. Five to 10 slices were pooled in a centrifuge tube and subsequently centrifuged for $10 \mathrm{~min}$ at $1770 \times g$ (Saager et al. 1990). 


\section{RESULTS}

\section{Porewater profiles and fluxes of oxygen and nutrients}

A representative oxygen profile is shown in Fig. 1. On average, oxygen penetrated $2.8 \pm 0.5 \mathrm{~mm}$ into the sediment, indicative for intense mineralisation processes occurring in this continental shelf sediment (Rasmussen \& Jørgensen 1992). The diffusive oxygen flux, as calculated by the zero-order model of Bouldin (1968), amounted to $234 \pm 20$ in Expt $\mathrm{A}$ and $254 \pm 45 \mu \mathrm{mol} \mathrm{O}_{2} \mathrm{~m}^{-2}$ $\mathrm{h}^{-1}$ in Expt B (Table 1). The molecular diffusion coefficient applied $\left(7.2 \times 10^{-5} \mathrm{~m}^{-2} \mathrm{~d}^{-1}\right)$ was corrected for temperature (Li \& Gregory 1974) and porosity (Ullmann \& Aller 1982).

A representative nitrate porewater profile (Fig. 2A) shows subsurface nitrate concentrations which were higher than those in the bottom water $(0.6 \mu \mathrm{M})$. The maximum concentration was observed in the oxic surface layer. In deeper, anoxic layers, nitrate concentrations declined sharply until a depth of $-6 \mathrm{~mm}$. Below that depth down to $70 \mathrm{~mm}$, the nitrate gradient decreased more gradually. Nitrite was a minor component of the $\mathrm{NO}_{\mathrm{x}}$ pool $(<8 \%)$ and was therefore ne-

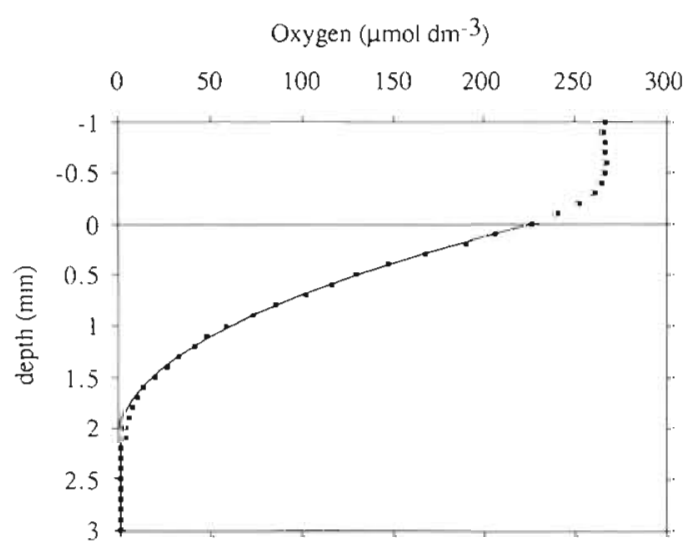

Fig. 1 Representative oxygen profile. Markers indicate the measured profile. Solid line represents the modelled zeroorder profile

Table 1 Fluxes $( \pm \mathrm{SD}$ ) of oxygen, ammonium and nitrate across the sediment-water interface during all experiments. Negative values denote uptake by the sediment. nd = no data

\begin{tabular}{|c|c|c|c|}
\hline Experiment & $\begin{array}{c}\mathrm{O}_{2} \text { flux } \\
\left(\mu \mathrm{mol} \mathrm{O}_{2} \mathrm{~m}^{-2} \mathrm{~h}^{-1}\right)\end{array}$ & $\begin{array}{l}\mathrm{NH}_{4}{ }^{+} \text {flux } \\
\quad(\mu \mathrm{mol} \mathrm{N}\end{array}$ & $\begin{array}{l}\mathrm{NO}_{3}^{-} \text {flux } \\
\left.\mathrm{m}^{-2} \mathrm{~h}^{-1}\right)\end{array}$ \\
\hline Expt A (D1) & $-234 \pm 20$ & $14.7 \pm 13.2$ & $9.8 \pm 4.3$ \\
\hline$B(D 2)$ & $-254 \pm 45$ & $16.1 \pm 5.2$ & nd \\
\hline$C(D 3)$ & nd & $1.9 \pm 1.8$ & $11.4 \pm 9.6$ \\
\hline $\begin{array}{l}\text { All } \\
\text { measurements }\end{array}$ & $\begin{array}{c}-244 \pm 35 \\
(n=6)\end{array}$ & $\begin{array}{c}10.9 \pm 10.4 \\
(n=9)\end{array}$ & $\begin{array}{c}10.6 \pm 7.5 \\
(n=6)\end{array}$ \\
\hline
\end{tabular}
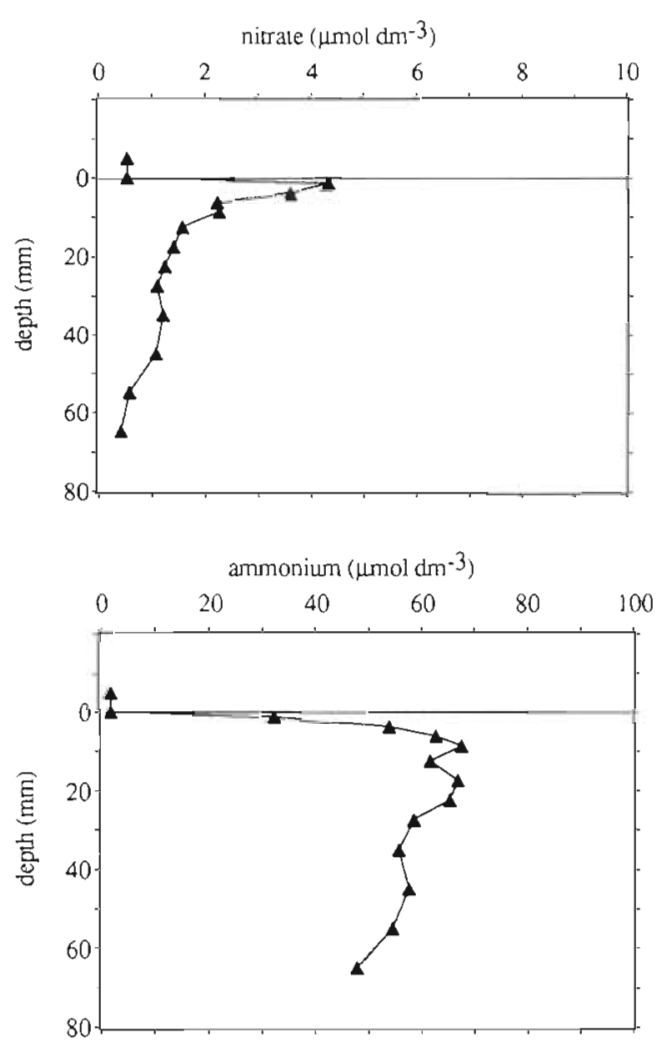

Fig. 2. Representative nitrate (upper panel) and ammonium (lower panel) profiles

glected. In agreement with the porewater profile, measured nitrate fluxes were always directed to the water column (Table 1). Nitrate effluxes were consistent with time, but showed large core-to-core variations.

The ammonium porewater concentrations increased directly below the sediment-water interface and revealed highest concentrations at $\sim 8 \mathrm{~mm}$ (Fig. 2B). Measured effluxes of ammonium across the sedimentwater interface were of a similar magnitude as the nitrate fluxes (Table 1).

\section{Denitrification rates}

Acetylene inhibition technique (AIT)

Acetylene amended cores showed an elevated content of $\mathrm{N}_{2} \mathrm{O}$ compared to the control cores (Fig. 3). In all experiments, the $\mathrm{N}_{2} \mathrm{O}$ concentrations in individual cores increased from $\sim 3 \mathrm{nmol}$ at $t=0$ to $\sim 5-6 \mathrm{nmol}$ per core after 40 to $65 \mathrm{~min}$. No further increase, but instead, a slight decrease in $\mathrm{N}_{2} \mathrm{O}$ occurred after $65 \mathrm{~min}$. Consequently, the calculated denitrification rates may depend on the period of their incubation (Fig. 4). The rates were highest in shortly incubated sediment cores ranging between 5.4 and $7.3 \mu \mathrm{mol} \mathrm{N} \mathrm{m}^{-2} \mathrm{~h}^{-1}$ (Table 2). 


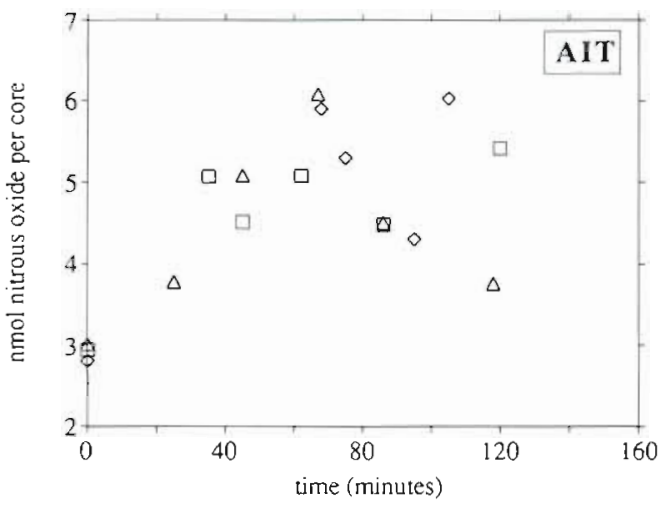

Fig. 3. Pooled $\mathrm{N}_{2} \mathrm{O}$ accumulation in individual cores in Expts $\mathrm{A}(\Delta), \mathrm{B}(\square)$ and $\mathrm{C}(\diamond), \mathrm{N}_{2} \mathrm{O}$ concentrations at $t=0$ represent the control cores incubated without acetylene

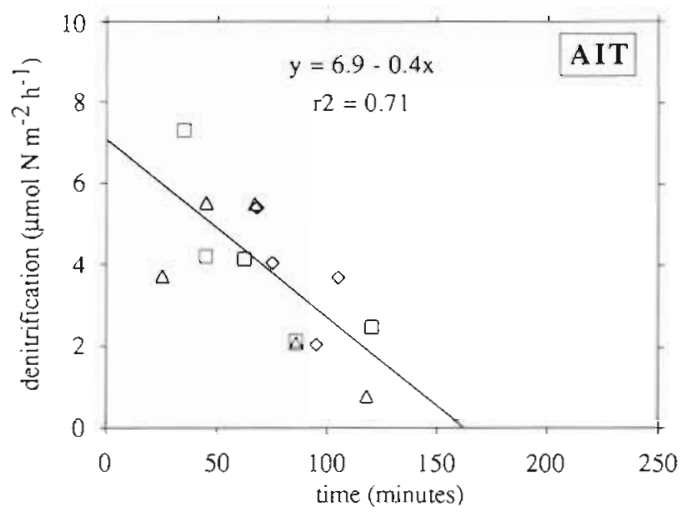

Fig. 4. Pooled denitrification rates in Expts $A(\Delta), B(\square)$ and $C$ $(\diamond)$. Solid line indicates linear regression through all denitrification rates

The negative correlation between denitrification rates and incubation time $\left(y=6.9-0.4 x, r^{2}=0.71\right)$ indicates that, when applying the AIT, the calculated denitrification rates become very low after incubations of longer

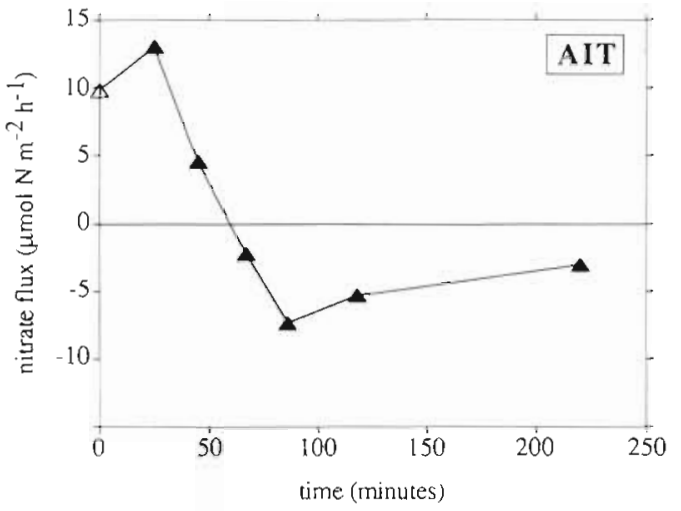

Fig. 5. Development of nitrate fluxes in Expt A in inclividual acetylene amended sediment cores during the incubation. Open symbol at $t=0$ denotes the nitrate flux in control cores

than 150 min. Previous experiments showed that $\mathrm{N}_{2} \mathrm{O}$ never accumulated in control cores incubated without acetylene (Lohse et al. 1993).

Nitrate fluxes measured in the acetylene amended cores were also dependent on the period of incubation. Fig. 5 shows the nitrate fluxes in Expt A. The initial nitrate efflux $\left(13.0 \mu \mathrm{mol} \mathrm{N} \mathrm{m}^{-2} \mathrm{~h}^{-1}\right)$ was similar to the flux measured in the cores without acetylene (Table 1) Continued incubation of the cores revealed decreasing effluxes turning to influxes after $\sim 65 \mathrm{~min}$. Similar influxes were observed for Expts $B$ and $C$ after approximately 1 h of incubation (data not shown).

\section{Isotope pairing method (IPM)}

Sediment cores incubated with a uniform concentration of either 61 (Expt A), 83 (B), or $62 \mu \mathrm{M}^{15} \mathrm{NO}_{3}{ }^{-}$(C) showed a regular accumulation of single-labelled $\left({ }^{14} N^{15} N\right)$ and double-labelled $\left({ }^{15} N^{15} N\right)$ dinitrogen isotopes (Fig 6, upper panels). More than $75 \%$ of the la-

Table 2. ${ }^{15} \mathrm{NO}_{3}$ concentration ( $\mu \mathrm{mol} \mathrm{l}{ }^{-1}$ ) and denitrification rates (all in $\mu \mathrm{mol} \mathrm{N} \mathrm{m}^{-2} \mathrm{~h}^{-1}$ ) based on labelled $\left(\mathrm{D}_{15}\right.$ ) and unlabelled $\left(D_{14}\right)$ nitrate $( \pm S D)$. Dn and Dw denote the denitrification rate depending on unlabelled nitrate provided from nitrification and from the overlying water, respectively. Initial AIT denotes highest denitnfication rates obtained from acetylene-amended cores analysed within the first $70 \mathrm{~min}$ after the start of the incubation

\begin{tabular}{|c|c|c|c|c|c|c|c|}
\hline \multirow{2}{*}{ Experiment } & \multicolumn{5}{|c|}{ IPM } & \multirow{2}{*}{ Initial AIT } & \multirow{2}{*}{ Ratio $D_{14} / A I T$} \\
\hline & {$\left[{ }^{15} \mathrm{NO}_{3}{ }^{-}\right]$} & $D_{15}$ & $D_{14}$ & Dn & Dw & & \\
\hline A & 61 & $55.8 \pm 3.6$ & $12.4 \pm 2.6$ & $11.6 \pm 2.8$ & $0.8 \pm 0.3$ & 5.5 & 2.2 \\
\hline B & 83 & $21.5 \pm 4.9$ & $11.6 \pm 2.0$ & $11.3 \pm 2.0$ & $0.2 \pm 0.0$ & 7.3 & 2.2 \\
\hline $\mathrm{C}$ & 62 & $37.0 \pm 9.8$ & $13.2 \pm 4.4$ & $12.6 \pm 4.2$ & $0.8 \pm 0.2$ & 5.4 & 2.4 \\
\hline$E$ & $15-180$ & - & $9.8 \pm 2.8$ & $9.4 \pm 2.4$ & $0.4 \pm 0.2$ & & \\
\hline All measurements & - & $\begin{array}{c}38.0 \pm 15.6 \\
n=15\end{array}$ & $\begin{array}{c}11.3 \pm 3.2 \\
n=28\end{array}$ & $\begin{array}{c}10.7 \pm 3.1 \\
n=28\end{array}$ & $\begin{array}{c}0.5 \pm 0.2 \\
n=28\end{array}$ & $\begin{array}{c}6.1 \pm 1.1 \\
\mathrm{n}=3\end{array}$ & $2.3 \pm 0.1$ \\
\hline
\end{tabular}



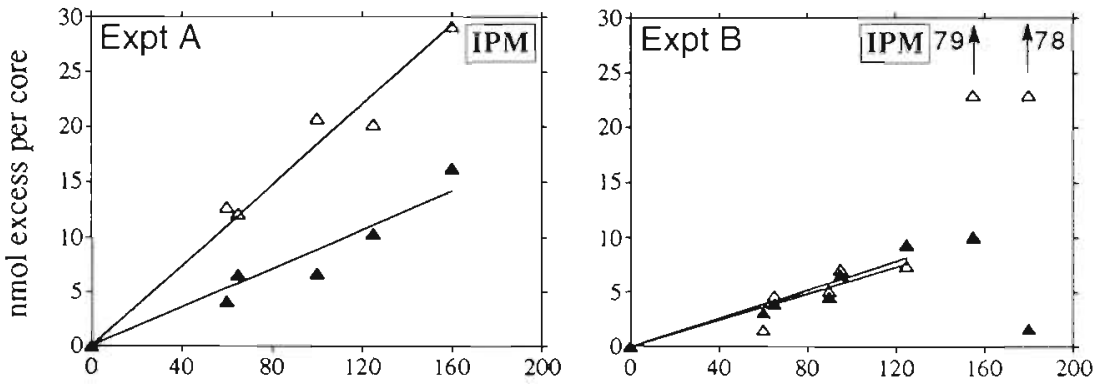

\section{IPM}
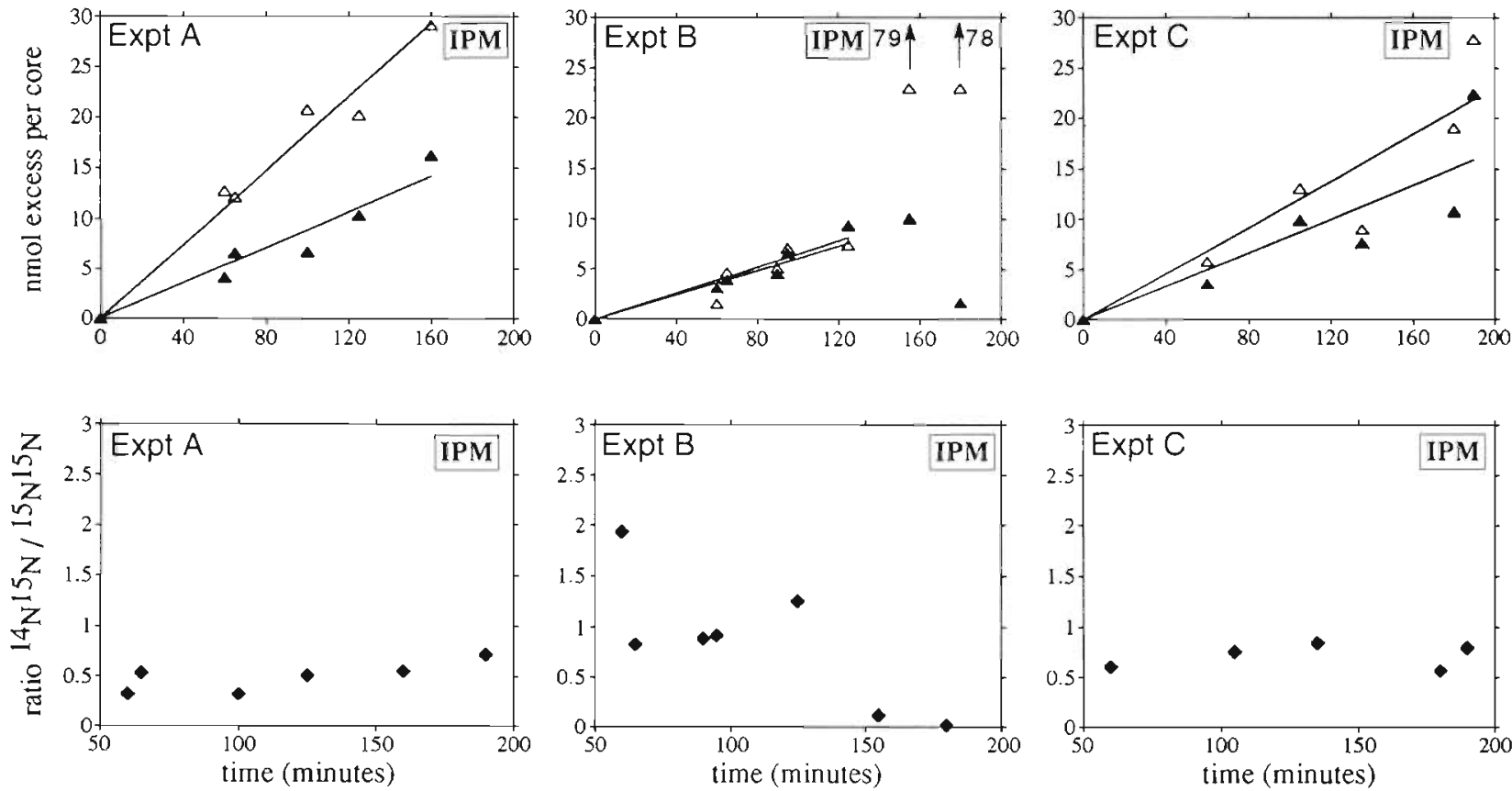

Fig. 6. Upper panels: development of excess of ${ }^{14} \mathrm{~N}^{15} \mathrm{~N}$ (closed symbols) and ${ }^{15} \mathrm{~N}^{15} \mathrm{~N}$ (open symbols) in Expts $\mathrm{A}, \mathrm{B}$ and $\mathrm{C}$ in individual sediment cores incubated with a uniform ${ }^{15} \mathrm{NO}_{3}{ }^{-}$concentration in the overlying water. Lower panels: ${ }^{2}$ atio of ${ }^{14} \mathrm{~N}^{15} \mathrm{~N} /{ }^{15} \mathrm{~N}^{15} \mathrm{~N}$ produced during the course of Expts A, B and C

belled isotopes produced were found in the sediment; the rest was released to the water column. The slope of the plotted ratios $\left({ }^{14} \mathrm{~N}^{15} \mathrm{~N}\right) /\left({ }^{15} \mathrm{~N}^{15} \mathrm{~N}\right)$ during the course of the incubation did not show significant differences from zero (Student $t$-test, $p=0.1$ ) (Fig. 6, lower panels), indicating that both isotopic nitrate species were denitrified with the same frequency. The low ratios found at the end of incubation $\mathrm{B}$ were caused by insufficient $\mathrm{ZnCl}_{2}$ addition, which permitted continued gas production in the exetainers as was observed from the swollen septas of the vacutainer. The denitrification rate of labelled nitrate $\left(D_{15}\right)$ was more variable than the rate of unlabelled nitrate $\left(D_{14}\right)$ (Table 2 ). Almost $95 \%$ of the denitrification rate based on unlabelled nitrate $\left(D_{14}\right)$ was supported by coupled nitrification-denitrification (Dn). Consequently, the downward diffusion of nitrate from the overlying water (Dw) to the anoxic denitrification zone was of minor importance in these particular North Sea sediments

Denitrification rates obtained from the cores incubated with different concentrations of ${ }^{15} \mathrm{NO}_{3}{ }^{-}$in the overlying water (Expt E) are shown in Fig. 7 . The $\mathrm{D}_{15}$ rates were correlated to the concentration of ${ }^{15} \mathrm{NO}_{3}{ }^{-}$in the overlying water. Coupled nitrification-denitrification (Dn) was apparently independent of the ${ }^{15} \mathrm{NO}_{3}{ }^{-}$ concentration. Within the applied range of 15 to $180 \mu \mathrm{M}{ }^{15} \mathrm{NO}_{3}^{-}$Dn was relatively constant around

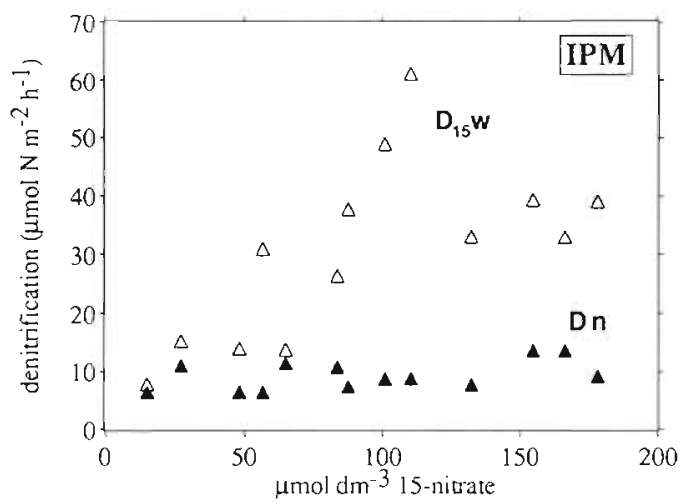

Fig. 7. Denutrification rates in individual sediment cores versus ${ }^{15} \mathrm{NO}_{3}{ }^{-}$concentration in the overlying water (Expt E). Denitrification of ${ }^{15} \mathrm{NO}_{3}{ }^{-}$coming from the overlying water $\left(D_{15} \mathrm{w}\right.$, $\triangle$ ) and produced by nitrification (Dn,

$9.8 \pm 2.8 \mu \mathrm{mol} \mathrm{N} \mathrm{m}{ }^{-2} \mathrm{~h}^{-1}$ (Table 2). At all ${ }^{15} \mathrm{NO}_{3}{ }^{-}$levels applied, the contribution of unlabelled nitrate in the overlying water (Dw) to the overall denitrification $\left(D_{14}\right)$ remained less than $5 \%$.

The in situ denitrification rate measured by the IPM, represented by the $D_{14}$ rate in Table 2 , exceeded the initial in situ denitrification rate obtained with the AIT by a factor of 2.2, 2.2 and 2.4 in Expts $A, B$ and $C$, respectively (Table 2). 


\section{DISCUSSION}

Our results indicate that in situ denitrification activity can be detected by both the isotope pairing method and the acetylene inhibition technique. However, rates computed from the AIT were always lower and more sensitive to the incubation time than the $D_{14}$ rates measured with IPM. Based on the nitrous oxide accumulation during the first $60 \mathrm{~min}$, the AIT detected $\sim 50 \%$ of the $\mathrm{D}_{14}$ rate measured by the IPM (Table 2). The nonconstant $\mathrm{N}_{2} \mathrm{O}$ accumulation with time indicates that the net rate of $\mathrm{N}_{2} \mathrm{O}$ production in the sediment changed within the first $2 \mathrm{~h}$ of incubation. The levelling off and successive decrease in the $\mathrm{N}_{2} \mathrm{O}$ in the sediment cores implies that $\mathrm{N}_{2} \mathrm{O}$ was close to zero or was even turned into a consumption after $\sim 60 \mathrm{~min}$.

The efficiency of the AIT in aquatic sediments depends on the availability of nitrate (Oremland et al. 1984, Rudolph et al. 1991). If sedimentary nitrification is the prevailing source of nitrate, a rapid exhaustion of the nitrate porewater pool may lead to underestimation of the true denitrification rate due to the coinhibition of nitrification by acetylene (Walter et al. 1979, Hyman \& Arp 1985). High subsurface nitrate concentrations in the porewater and the net effluxes of nitrate across the sediment-water interface imply that nitrification is the predominant nitrate source in the present study. We found production of nitrous oxide as long as the incubation time was shorter than -60 min. Evidently, the pool of porewater nitrate was not exhausted during this initial stage of the experiment. This conclusion is supported by the simultaneously measured nitrate effluxes in the first hour of the experiment, which were similar to nitrate effluxes measured in control cores without acetylene (Fig. 5). The maximum nitrate influxes measured after $\sim 70$ min were larger than the denitrification rates measured during the initial stage of the experiment. This suggests that the denitrification rate based on the initial $\mathrm{N}_{2} \mathrm{O}$ was lower than the true denitrification rate. Probably the inhibition of the $\mathrm{N}_{2} \mathrm{O}$ reductase was also incomplete during the initial period of the experiment. This is supported by studies with combined $\mathrm{N}_{2} \mathrm{O}$ and $\mathrm{O}_{2}$ sensors (Christensen et al. 1989, Nielsen et al. 1990). These studies have demonstrated that up to $40 \%$ of the accumulated $\mathrm{N}_{2} \mathrm{O}$ may be reduced in deeper, anoxic layers, despite the presence of acetylene. Experiments with sediment slurries have shown that nitrous oxide can be reduced in the presence of acetylene as soon as the nitrate concentration decreases below 5 to $10 \mu \mathrm{M}$ (Slater \& Capone 1989). Since the nitrate porewater concentration in the denitrification zone of our sediments was in this range, we conclude that the accumulation of $\mathrm{N}_{2} \mathrm{O}$ ceased after 50 to 70 min due to an exhaustion of the nitrate pore- water pool. The presupposition for this conclusion is that dissimilative nitrate reduction to ammonia does not play a substantial role in these sediments. Dissimilative nitrate reduction to ammonium normally does not account for more than $5 \%$ of the total nitrate uptake in estuarine sediments (Pelegri et al. 1994, Risgaard-Petersen et al. 1994). The maximum nitrate influx in the acetylene amended cores was close to the denitrification rate measured with the IPM. As denitrification is the only nitrate consuming process in acetylene amended cores, the maximum nitrate influx rather than the nitrous oxide accumulation may give a fairly good estimate for the true denitrification rate.

The major challenge of the isotope pairing technique is to apply an appropriate ${ }^{15} \mathrm{NO}_{3}{ }^{-}$concentration in the sediment which on the one hand entraps all ${ }^{14} \mathrm{NO}_{3}{ }^{-}$ molecules denitrified, but on the other hand does not influence the uptake of ${ }^{14} \mathrm{NO}_{3}{ }^{-}$by the denitrifying bacteria. Concentrations of ${ }^{15} \mathrm{NO}_{3}{ }^{-}$which are too low may result in a deviation of the assumed binomial distribution of the $\mathrm{N}_{2}$, and thus in an underestimate of the Dn rate due to a higher formation of unlabelled relative to single- and double-labelled $\mathrm{N}_{2}$. The ratio between the isotopic species $\left({ }^{14} \mathrm{~N}^{15} \mathrm{~N} /{ }^{15} \mathrm{~N}^{15} \mathrm{~N}\right)$ should remain below 2 , since this indicates that all produced ${ }^{14} \mathrm{NO}_{3}{ }^{-}$molecules have paired with ${ }^{15} \mathrm{NO}_{3}{ }^{-}$. The ratio will further decrease as the concentration of added ${ }^{15} \mathrm{NO}_{3}{ }^{-}$ increases. However, the ${ }^{15} \mathrm{NO}_{3}{ }^{-}$concentration cannot be infinitely high, since the first order kinetics of denitrifying bacteria with respect to $\mathrm{NO}_{3}^{-}$(Christensen et al. 1990, Jensen et al. 1994) should be maintained to guarantee that the uptake kinetics of ${ }^{14} \mathrm{NO}_{3}{ }^{-}$are not affected. The $\mathrm{D}_{14}$ rate was independent of the ${ }^{15} \mathrm{NO}_{3}{ }^{-}$ concentration, whereas $D_{15}$ responded according to first-order kinetics (Fig. 7). This is in line with previous studies using isotope pairing (Pelegrí et al 1994, Rysgaard et al. 1994). From this, we conclude that the major assumptions underlying the IPM were met, and that within the constraints given for this technique (Nielsen 1992), the IPM data $\left(D_{14}\right)$ represent a reliable estimate for the in situ denitrification rates.

\section{Denitrification in North Sea sediments}

Previously reported estimates of denitrification in North Sea sediments were based either on the AIT or on diagenetic modelling of porewater profiles. Investigators using the former approach found rates between 0.6 and 12 (Law \& Owens 1990), 1 and 23 (van Raaphorst et al. 1992) and 0 to $8.2 \mu \mathrm{mol} \mathrm{N} \mathrm{m}^{-2} \mathrm{~h}^{-1}$ (Lohse et al. 1993). When only considering rates measured in summer in the direct vicinity of our study site, both the AIT and the IPM/D $D_{14}$ in this study gave higher values than those reported in the literature. Law \& 
Owens (1990), van Raaphorst et al. (1992) and Lohse et al. (1993) found rates of $0.6,2.1$ and $0.5 \mu \mathrm{mol} \mathrm{N} \mathrm{m}{ }^{-2} \mathrm{~h}^{-1}$, respectively. The average of these estimates $(1.1 \pm$ $0.7 \mu \mathrm{mol} \mathrm{N} \mathrm{m} \mathrm{N}^{-2} \mathrm{~h}^{-1}$ ) represents only $18 \%$ of our average AIT value. The percentage is as low as $9 \%$ when comparing the literature data to the rates obtained from the IPM. Although interannual and spatial variability have probably contributed to the discrepancies among the AIT rates, it is obvious that the incubation times used in previous investigations (up to $16 \mathrm{~h}$ ) were too long to match initial nitrous oxide accumulation. It thus seems likely that previous data severely underestimated true denitrification rates. This conclusion is confirmed by denitrification rates calculated from diagenetic porewater models, obtained in the same season close to our sampling site (van Raaphorst et al. 1990). Rates based on these diffusive porewater fluxes ranged from 6.3 to $9.8 \mu \mathrm{mol} \mathrm{N} \mathrm{m} \mathrm{N}^{-2} \mathrm{~h}^{-1}$ and are considerably higher than previous estimates based on the AIT, but differ only by a factor of 1.5 from the IPM values in the present study. These results and the ratio we report between the IPM/D $\mathrm{D}_{14}$ and the AIT (Table 2) strongly suggest that the $D_{14}$ rates obtained from the IPM represent more accurate values for denitrification than do the AIT rates.

We have previously postulated that the steep diffusive nitrate gradients across the sediment-water interface may favour the release of nitrate to the overlying water column instead of its denitrification in deeper anoxic layers (Lohse et al. 1993). Our data confirm that a substantial amount of nitrate produced by nitrification diffuses to the nitrate-depleted water column. Assuming that the nitrification rate is given by the sum of the nitrate efflux plus the initial AIT denitrification rate, between 64 (Expt A) and $68 \%$ (Expt B) of the nitrate produced diffuses to the overlying water. Using the IPM Dn rates as a more accurate estimate, we obtain values between 46 (Expt A) and 48\% (Expt C). These results are in line with laboratory experiments (Sloth et. al. 1995) and modelling studies (Blackburn \& Blackburn 1993, Ruardij \& van Raaphorst 1995). It follows that approximately half of the nitrate produced in the sediment reaches the anoxic layers to be denitrified.

The inorganic nitrogen cycle in these continental shelf sediments of the North Sea can be summarised by assuming that nitrification equals the sum of the average nitrate efflux (Table 1) and the Dn denitrification rate (Table 2). Inferring the total $\mathrm{N}$-mineralisation from the sum of nitrification plus the ammonium efflux (Table 1), we obtain a mineralisation rate of $32 \mu \mathrm{mol} \mathrm{N} \mathrm{m} \mathrm{N}^{-2} \mathrm{~h}^{-1}$. About one third of the ammonium produced diffused out of the sediment, while two thirds was nitrified to $\mathrm{NO}_{3}{ }^{-}$; about $50 \%$ of the nitrate produced diffused out of the sediment, while the other $50 \%$ was denitrified. Hence, about $33 \%$ of the remineralised nitrogen left the sediment in the form of ammonium, $32 \%$ left as nitrate and $35 \%$ as gaseous dinitrogen. This high percentage of denitrification points out the important role this process plays in benthic $\mathrm{N}$-cycling. A shift of the anoxic-oxic interface deeper into the sediment due to lower mineralisation activity in winter (as previously observed in Lohse et al. 1995) may result in a relatively higher percentage of ammonium being nitrified and subsequently denitrified, although the absolute rates may be lower due to less intense nitrogen mineralisation.

The results obtained in this study confirm the importance of benthic denitrification but also show that the shallow continental shelf sediments of the North Sea return most of the deposited nitrogen compounds to the water column as ammonium and nitrate. This situation generally holds for shallow sediments overlain by a nitrogen-poor, well-oxygenated water column where nitrification predominantly controls denitrification. In contrast, shelf sediments overlain by water columns with low oxygen and high nitrate concentrations may act as a sink for nitrogen compounds, since here denitrification is also supported by nitrate originating from the overlying water.

Acknowledgements. We express our gratitude to Captain J. C. Groot and the crew of the RV 'Pelagia' who provided a safe and pleasant cruise. We are also indebted to Søren Rysgaard and Preben Sørensen (National Environmental Research Institute, Denmark) for their support and advice during the mass-spectrometric ${ }^{15} \mathrm{~N}$ measurements. Porewater and sediment characteristics were measured by Hans Malschaert. Evaline van Weerlee and Annette van Koutrik (nutrient analysis group, Department of Chemical Oceanography) performed the nutrient analysis. This work was partly subsidised by the Dutch Government (BEON grant no. NIOZ 94/95 E-01 RKZ 161/061). This is publication no. 85 of the project Applied Scientific Research (BEWON), at the Netherlands Institute for Sea Research.

\section{LITERATURE CITED}

Blackburn TH, Blackburn ND (1993) Coupling of cycles and global significance of sediment diagenesis. Mar Geol 113: $101-110$

Blackburn TH, Nedwell DB, Wiebe WJ (1994) Active mineral cycling in a Jamaican seagrass sediment. Mar Ecol Prog Ser 110:233-239

Bouldin DR (1968) Models for describing the diffusion of oxygen and other mobile constituents across the mud-water interface. J Ecol 56:77-87

Christensen PB, Nielsen LP, Revsbech NP, Sørensen J (1989) Microzonation of denitrification activity in stream sediments with a combined oxygen and nitrous oxide microsensor. Appl environ Microbiol 55:1234-1241

Christensen PB, Nielsen LP, Sorensen J, Revsbech NP (1990) Denitrification in nitrate-rich streams; diurnal and seasonal variation related to benthic oxygen metabolism. Limnol Oceanogr 35:640-651

Devol AH, Christensen JP (1993) Benthic fluxes and nitrogen Cycling in sediments of the continental margin of the eastern North Pacific. J mar Res 51:345-372 
Hauck RD, Melsted SW, Yankwich PE (1958) Use of N-isotope distribution in nitrogen gas in the study of denitrification. Soil Sci 86:287-291

Helder W, de Vries RPT (1979) An automatic phenol-hypochlorite method for the determination of ammonia in seaand brackish waters. Neth J Sea Res 13:154-160

Hyman MR, Arp DJ (1985) Suicida! labelling and inactivation of ammonia mono-oxygenase by acetylene. Biochem $\mathrm{J}$ 227:207-214

Hyman MR, Arp DJ (1987) Quantification and removal of some contaminating gases from acetylene used to study gas-utilizing enzymes and microorganisms. Appl environ Microbiol 53:298-303

Jensen K, Sloth NP, Risgaard-Petersen N, Rysgaard S, Revsbech NP (1994) Estimation of nitrification and denitrification from microprofiles of oxygen and nitrate in model sediment systems. Appl environ Microbiol 60:2094-2100

Jensen MH, Andersen TK, Sørensen J (1988) Denitrification in coastal bay sediment: regional and seasonal varation in Aarhus Bight, Denmark. Mar Ecol Prog Ser 48:155-162

Kemp WM, Sampou P, Caffrey J, Mayer M, Henriksen K, Boynton WR (1990) Ammonium recycling versus denitrification in Chesapeake Bay sediments. Limnol Oceanogr 35:1545-1563

Law CS, Owens NJP (1990) Denitrification and nitrous oxide in the North Sea. Neth J Sea Res 25:65-74

Li YH, Gregory S (1974) Diffusion of ions in sea water and in deep sea sediments. Geochim cosmochim Acta 38: $703-714$

Lohse L, Malschaert JFP, Slomp CP. Helder W, van Raaphorst W (1993) Nitrogen cycling in North Sea sediments: interaction of denitrification and nitrification in offshore and coastal areas. Mar Ecol Prog Ser 101:283-296

Lohse L, Malschaert JFP, Slomp CP. Helder W, van Raaphorst W (1995) Sediment-water fluxes of inorganic nitrogen compounds along the transport route of organic matter in the North Sea. Ophelia 41:173-197

Nielsen LP (1992) Denitrification in sediment determined from nitrogen isotope pairing. FI: TS Microbiol Ecol 86 $357-362$

Nielsen LP, Christensen PB, Revsbech NP, Sorensen J (1990) Denitrification and photosynthesis in stream sediment studied with microsensor and whole-core techniques. Limnol Oceanogr 35:1135-1144

Nishio T, Koike I, Hattori A (1983) Estumates of denitrification and nitrification in coastal and estuarine sediments. Appl environ Microbiol 45:444-450

Nixon SW (1981) Remineralisation and nutrient cycling in coastal marine ecosystems. In: Neilson B, Cronin LE (eds) Nutrient enrichment in estuaries. Humana Press, Clifton, NJ, p $111-138$

Nowicki BL (1994) The effect of temperature, oxygen, salinity, and nutrient enrichment on estuarine denitrification rates measured with a modified nitrogen gas flux lechnique. Estuar coast Shelf Sci 38:137-156

Oremland RS, Umberger C, Culbertson CW, Smith R: A (1984) Denitrification in San Francisco Bay intertidal sediments. Appl environ Microbiol 47:1106-1112

Pelegrí SP, Nielsen LP, Blackburn TH (1994) Denitrification in estuarine sediment stimulated by the irrigation activity of the amphipod Corophium volutator. Mar Ecol Prog Ser 105:285-290

Rasmussen H, Jørgensen BB (1992) Microelectrode studies of seasonal oxygen uptake in a coastal sediment: role of molecular diffusion. Mar Ecol Prog Ser 81:289-303

Revsbech NP, Jørgensen BB (1986) Microelectrodes: their use in microbial ecology, In: Marshall KC (ed) Advantages in microbial ecology 9. Plenum, New York, p 293-351

Risgaard-Petersen N, Rysgaard S, Nielsen LP, Revsbech NP (1994) Diurnal variation of denitrification and nitrification in sediments colonized by benthic microphytes. Limnol Oceanogr 39:573-579

Rönner $U$ (1985) Nitrogen transformations in the Baltic proper: denitrification counteracts eutrophication. Ambio $14: 134-138$

Ruardij P, van Raaphorst W (1995) Benthic nutrient regeneration in the ERSEM ecosystem model of the North Sea. Neth J Sea Res 33:453-483

Rudolph J, Frenzel P, Pfennig N (1991) Acetylene inhibition technique underestimates in situ denitrification rates in intact sediment cores of freshwater sediment. FEMS Microb Ecol 85:101-106

Rysgaard S, Risgaard-Petersen $N$, Sloth NP, Jensen $K$ Nielsen LP (1994) Oxygen regulation of nitrification and denitrification in sediments. Limnol Oceanogr 39: $1643-1652$

Saager PM, Sweerts JP, Ellermeijer HJ (1990) A simple porewater sampler for coarse, sandy sediments of low porosity. Limnol Oceanogr 35:747 ij1

Seitzinger SP (1987) Nitrogen biogeochemistry in an unpolluted estuary: the importance of benthic denitrification. Mar Ecol Prog Ser 37:65-73

Seitzinger SP (1988) Denitrification in freshwater and coastal marine ecosystems: ecological and geochemical evidence. Limnol Oceanogr 33:702-724

Seitzinger SP (1990) Denitrification in aquatic sediments. In: Revsbech NP, Sørensen J (eds) Denitrification in soil and sediment. FEMS Symposium, Plenum Press, New York, $p$ 301-322

Seitzinger SP, Nielsen LP, Caffrey J, Christensen PB (1993) Denitrification in aquatic sediments: a comparison of three methods. Biogeochemistry 23:147-167

Seltzinger SP, Nixon S, Pilson MEQ, Burke S (1980) Denitrif 1 cation and $\mathrm{N}_{2} \mathrm{O}$ production in near-shore marine sediments. Geochim cosmochim Acta 44:1853-1860

Slater JM, Capone DG (1989) Nitrate requirement for acetylene inhibition of nitrous oxide reduction in marine sediments. Microb Ecol 17:143-157

Sloth NP, Blackburn TH, Hansen LS, Risgaard-Petersen N, Lomstein BA (1995) Nitrogen cycling in sediments with different organic loads. Mar Ecol Prog Ser 116:163-170

Sørensen J (1978) Denitrification rates in a marine sediment as measured by the acetylene inhibition technique. Appl environ Microbiol 36:139-143

Strickland JD, Parsons TR (1972) A practical handbook of seawater analysis, 2nd edn. Bull Fish Res Bd Can 167 71-76

Thompson SA, Paerl HW, Go MC (1995) Seasonal patterns of nitrification and denitrification in a natural and a restored salt marsh. Estuaries 18:399-408

Ullman WJ, Aller RC (1982) Diffusion coefficients in nearshore marine sediments. Limnol Oceanogr 27:552-556

van Raaphorst W, Kloosterhuis HT, Berghuis EM, Gieles AJM, Malschaert JFP, van Noort GJ (1992) Nitrogen cycling in two types of sediments of the southern North Sea (Frisian Front, Broadfourteens): field data and mesocosm results. Neth J Sea Res 28:293-316

van Raaphorst W, Kloosterhuis HT, Cramer A, Bakker KJM (1990) Nutrient early diagenesis in the sediments of the Dogger Bank area, North Sea: pore water results. Neth J Sea Res 26:25-52

Walter HM, Keeney DR. Fillery IR (1979) Inhibition of nitrification by acetylene. Soil Sci Soc Am J 43:195-196

Weiss RF (1970) The solubility of nitrogen, oxygen and argon 
in seawater. Deep Sea Res 17:721-735

Weiss RF, Price BA (1980) Nitrous oxide solubility in water and seawater. Mar Chem 8:347-359

This article was submitted to the editor
Yoshinari T, Knowles R (1976) Acetylene inhibition of nitrous oxide reduction by denitrifying bacteria. Biochem biophys Res Commun 69:705-710

Manuscript first received: April 18, 1995

Revised version accepted: August 29, 1995 